\title{
Effect of Health Education Program on Menstrual Practices Among Secondary School Girls
}

\author{
Heba Ali Hamed Mohamed, Prof. Dr. Effat Mohamed El-Karmalawy, Dr. Naglaa Ibrahim \\ Gida, Dr. Fatma El-Emam Hafez ${ }^{4}$. \\ M.Sc. in Community Health Nursing, Faculty of Nursing, Benha University. Professor of \\ Community Health Nursing, Faculty of Nursing, Cairo University; Lecturer of Family and \\ Community Health Nursing, Faculty of Nursing, Port Said University;
}

\begin{abstract}
Background: Onset of menstruation is one of the most important changes occurring during adolescence. The aim of this study was to evaluate the effect of health education program on menstrual practices among secondary school girls. Subjects and Method: A quasi-experimental research design was used in carrying out this study. The study was conducted in four governmental public secondary schools for girls in Damietta city. One hundred and thirty three female students fulfilled the study criteria were included in the study. A structured interviewing Questionnaire sheet and hygienic facilities observational checklist' for secondary schools were utilized as tools for collecting data. Post-test was done after 3 months to assess the impact of the program. Results showed that more than two-thirds of the studied students in the pre test reported having symptoms of RTI, in the post test, these symptoms slightly decreased but the difference observed wasn't statistically significant. Most of the students had healthy practice score level regarding all aspects related to menstrual hygiene in the post-test compared to the pre-test. The majority of them abstained from performing normal activities in the pre test. Meanwhile, In the post test, highly statistical significant differences were seen with regard to the previous items, where $(\mathrm{P}$-value $=$ 0.001). There was highly statistical significant difference between studied students' total practice score levels and their social class. Conclusion \& recommendations: The educational program was successful in attaining its aim of positively changing practices and behaviors of the studied students regarding menstruation. School health nurse should provide loud and clear messages on menstrual hygiene for adolescent girls and their mothers which can be achieved through parent meetings and group discussion based on scientific facts, considering physical, social and mental changes of adolescent girls. Secondary school students need to be supported with clean school environment supplied with clean bathrooms in addition to other basic hygienic products to help them manage their hygiene.
\end{abstract}

Keywords: Adolescent, Menstruation, Health education 


\section{INTRODUCTION}

Adolescence in girls is a phase of transition from girlhood to womanhood and marks the onset of female puberty. Approximately $9 \%$ (one fifth) of the world's population is in the age group of 10-19 years and adolescents constitute $25 \%$ of the population of Egypt. As they are passing through a transitional period, they are undergoing a lot of physical, behavioral as well as psychological stress due to the changes taking place in the body, the most notable being the onset of menstruation (Datta et al, 2012\& Dube and Sharma, 2012).

Menstrual hygiene deals with a woman's special health care needs and requirements during her monthly menstruation or menstrual cycles. These areas of special concern include choosing the best period protection, or feminine hygiene products, how often and when to change her feminine hygiene products, bathing, care of her vulva and vagina. Primarily poor personal hygiene and unsafe sanitary conditions result in gynecological problems. Hygienic practices related to menstruation, like prolonged use of these pieces of cloth absorbent, inappropriate laundering of the cloth absorbent and improper perineum care create an environment for harboring harmful microorganisms that may affect the urinary tract and also infect the perineum (Sowmya and Mohan, 2012\& Juyal and Negi, 2012).

Although menstruation is a natural process, it is linked with several misconceptions. Societies hand down traditions from generation to generation by teaching certain practices, legends, customs, and habits. Girls usually share whatever local customs and beliefs their parents practice. Some traditional practices are useful, while some are harmful and some are harmless. Faulty perceptions or misconceptions on menstruation and menstrual cycle will lead to faulty menstrual practices. Either of these may engender reproductive health problems in the adolescent (Abd El-Hameed et al., 2011).

Menstrual education is a vital aspect of health education. It is known that attitudes to menstruation and menstrual practices developed at menarche may persist throughout life. The study of the menstrual practices of adolescent girls provides the basis for formulating health education strategies relevant for this crucial period in reproductive life (Aniebue et al, 2009). 
School health nurse play a key role central to public education on health hygiene and personal development. They can play a very important role in transmitting the vital message of correct menstrual hygiene to the adolescent girl of today. School health nurse can indirectly wipe away the age-old wrong ideas among girls and make them feel free to discuss menstrual matters including cleaner practices without any hesitation (Adika et al., 2013).

Hygiene-related practices of women during menstruation are of considerable importance for reproductive health. If poorly managed, it affects health by increasing vulnerability to Reproductive Tract Infections(RTIs), Pelvic Inflammatory Diseases(PIDs) and other complications (Dasgupta \&Sarkar, 2008). A study was conducted in Zagazig City at Sharqia governorate, Egypt, among secondary school students revealed that $51.3 \%$ of students had inadequate menstrual hygiene ( $\boldsymbol{A} \boldsymbol{b} \boldsymbol{d}$ Allah and Elsabagh 2011). Moreover, the study conducted in Benha city at Qaliubyia Governorate, Egypt, revealed that over all prevalence of symptoms of RTI due to unhealthy hygienic practices was as high $65.7 \%$ among the studied students (Mohamed, 2013).

Learning about hygiene during menstruation is a vital aspect of health education for adolescent girls as patterns that are developed in adolescence are likely to persist into adult life. Good menstrual hygiene is an important sanitation issue. Therefore, increased knowledge about menstruation and hygienic practices may escalate safe practices and may help in mitigating the suffering of millions of females (Shah et al., 2013). Therefore; the researcher decided to assess the effect of menstrual education program on students' menstrual practices and therefore, improving their health practices.

\section{AIM OF STUDY:-}

To evaluate the effect of health education program on menstrual practices among secondary school girls in Damietta City. 


\section{Research Objectives}

1. Finding out the status of menstrual hygiene among secondary school girls.

2. Identifying behaviors and restrictions related to menstruation among secondary school girls.

3. Designing health education program for secondary school girls in order to improve their practices and behaviors regarding menstruation.

4. Determining the change in menstrual practices and behaviors among secondary school girls after the educational program.

\section{Research Hypothesis:}

It was hypothesized that there will be a significant improvement in students' menstrual practices and behaviors after the program.

\section{SUBJECTS AND METHOD:}

\section{Study Design \& Setting}

The study was carried out using a quasi-experimental research design. It was carried out in all governmental public secondary schools for girls in Damietta city, which included; Othman Ibn Affan, Umm El Mo'mneen, Omar Ibn Al- Khattab and Ellouzy secondary school for girls.

\section{Study Sample}

After reviewing registration records of students in the prementioned schools in the three grades to estimate the total number of students to be enrolled in the study, registration records revealed that students enrolled at first year represented $34.9 \%$ of the total number of students in the prementioned schools, representing the target research population.

First grade registration record of each school was reviewed to detect the total number of students (1337) out of which representative sample of $10 \%$ was taken as study sample. Therefore, the estimated sample size was 133 students fulfilling the following inclusion criteria; female students who were menstruating and enrolled at first grade who accepted to participate in the study. Students to be enrolled in the study were selected from each school according to the following equation: 


\section{Number of students to be selected from each school =}

No of students at first grade/each school $\times$ Number of the sample size (133)

Total number of students at First grade in the (4) schools (Abd-Ella, 2010).

By using a list of students' names \& classes with the cooperation of school manager in each of the prementioned schools, students to be included in the study were selected by selecting one class randomly from first grades' classes in each school.

Tools of data collection: Data were collected using the following two tools.

Tool I: Structured Interviewing Questionnaire Sheet: It was developed by the researcher and composed of five main parts. The first part was developed to collect data related to socio-demographic characteristic of students that included questions about educational level of parents, occupation, residence, family size and income. Socioeconomic status of the studied students(SES) was calculated according to $\boldsymbol{E l}$ Gilany, et al.(2012.), which included 7 domains covering( paternal education \& occupation, income, family size, family possessions, home sanitation, family income and the usual source of family health care). The total score was 84. SES was classified into four levels depending on the quartiles of the score calculated: those with score range from $1-21$, from $22-42$, from $43-63$ and from $64-84$ were classified as very low, low, middle and high social levels respectively. The second part included characteristics of menstrual cycle and health complains among students. This part included (5) multiple choice questions about characteristics of students' menstrual cycle including (age at menarche, reaction to menarche, regularity of menstruation, duration and length of menstruation). In addition this part contained 2 multiple choice questions for assessing students' menstrual complains(premenstrual syndrome and menstrual symptoms). Also, there were 3 multiple choice questions for assessing students' current health complains including; characteristics of vaginal discharge according to its odor, color, consistency, texture, and associated signs of infection.

The third part of the tool included health practices among students regarding menstrual hygiene which encompassing (15) multiple choice questions about the practices related to; cleaning perineal area \& methods of cleaning, direction of care, 
dryness of perineal area, bathing during menstrual cycle, type of towels used during menstruation \& frequency of changing it, applying talcum powder and perfumed materials on the perineum, removal of pubic hair, washing hands, type of underwear , frequency of changing it, routes of cleaning and disposal of sanitary pads.

As for the scoring system of students' practices, a healthy practice was scored (1) and the unhealthy (zero). Final practice score was categorized ; healthy if the percent score was $\geq$ $75 \%$ and unhealthy if the percent score was $<75 \%$.

The fourth part included (10) questions for assessing girls' behaviors and restrictions during menstruation as school attendance, performing household activities, visiting the (holy places, relatives and friends during menses), performing physical activities, taking medications and herbs for pain relief. The fifth part included students' sources of information about menstruation. It included (4) questions about students' sources of information about menstruation, time of receiving this information, barriers encountered for seeking health advice regarding menstrual problems and the role of school health nurse in menstrual education

Tool II: School hygienic facilities observational checklist'. It was developed by the researcher to assess health facilities in each of the four schools. it included (14) questions about availability of clean water closets, sufficient water closets /students number, availability of water supply, basins for hand washing, location of these basins, soap or disinfectant solution to wash hands, availability of toilet paper, sufficient baskets for waste disposal in bathrooms, doors \& windows of water closets. It also included questions about existence of medical clinic and its own team (school doctor and school nurse) In addition, it included question about school library if it contain any materials related to menstruation and menstrual hygiene.

\section{Tool Content Validity and Reliability:}

Tools of data collection was developed by the researcher and it was tested for content validity by a panel of three experts in the field of community health nursing and obstetric nursing. The reliability was assured by calculating cronbach's alpha coefficients for each factor, it was high; it ranged from ( 0.75 to 0.88 ). 


\section{Pilot study:}

The pilot study was carried out on $10 \%$ of study sample which included(13) students, who were selected randomly from one of the four schools. It was done to ascertain the relevance, clarity and applicability of the developed tool and to estimate the time needed to fill the questionnaire sheet. Those girls who shared in the pilot study were excluded from the main study sample as a result of the modifications made to the questionnaire sheet, where some of the questions were added and others were omitted especially in the parts related to students' knowledge and practices.

\section{Administrative and Ethical Considerations:}

An official permission was obtained by submission of an official letter from the Faculty of Nursing to the responsible authorities of the study setting to obtain the authorization for data collection. The aim of the study was explained to every student before participation, and voluntary participation was emphasized and an oral consent was obtained.

\section{Statistical Analysis}

Data entry and statistical analysis were done using SPSS 16.0 statistical software package. Data were presented using descriptive statistics in the form of frequencies and percentages for qualitative variables, and means and standard deviations for quantitative variables. Qualitative categorical variables were compared using chi-square test. Whenever the expected values in one or more of the cells in a $2 \times 2$ tables was less than 5, Fisher exact test was used instead.

\section{Field Work:}

The study was implemented through the following four phases: assessment, program development, implementation, and evaluation. Collection of the data covered a period of six months from 1st of October 2014 to the end of March 2015.

\section{Assessment Phase}

After preparing the tool, the study sample was recruited according to the set criteria. Pretested questionnaire was administered to the study sample. Data collection from the students was performed in the free time during the school day. Schools were visited three days/week from the beginning to the end of the school day. The researcher interviewed female students after introducing herself and took the consent of them to be recruited in the study after explaining the aim of the study and then distributed the questionnaire sheet after 
clear explaining the way to fill out. During this phase of assessment, accurate observation has been done for each of the four schools for identifying school health protective measures especially school toilets and its supplies to make sure it is clean and contain the necessary elements that enable students to deal with their menstrual period. Those observations were presented to the school directors .The researcher have taken a promise from the school directors of trying to provide and improve the necessary health protective measures as much as possible to maintain students' health.

\section{Program Development Phase}

Based on the information obtained from initial assessment, in addition to literature, the researcher designed the educational program under the guidance of the supervisors. A simple booklet was developed for students which covered all items related to menstruation. The Educational booklet was written in simple Arabic language with different illustrated colored pictures. It included four sessions. The first session covered brief description of the female reproductive system . The second session covered physiology of menstruation and menstrual cycle characteristics. The third session was concerned with menstrual hygiene. The fourth session involved nutrition and physical exercise during menstruation.

\section{Program Implementation Phase}

The participating students were divided into eight groups of 14-18 each. The program was conducted through four sessions; each group obtained two sessions /week, each session took about one hour. The total allocated time for achieving the whole program to the eight groups was 32 hours ( 8 groups $\times 4$ hours). At the beginning of the first session, an orientation to the aim of the study and the goals of the program took place. Also, students were oriented about the phases of the study and the program sessions (time, duration, place, and contents). The researcher stressed on the importance of continuous attendance and active participation. Different teaching and learning methods were used during the sessions which included; interactive lecture, group discussion, demonstration \& redemonstration, instructional media included data show \& lab models and printed handout.

\section{Evaluation Phase}

The effectiveness of the program was evaluated three months after program implementation (post-test) using the same tool. Moreover, the same observational checklist for school health protective measures was filled (post test). 


\section{RESULTS:-}

Table (1) shows distribution of the studied students according to their socio demographic data. As evident in the table, the mean age of the studied students was $15.28 \pm 0.47$ years. In addition, $80.5 \%$ of them were living in urban areas. The table also showed that $53.4 \%$ of the students' mothers completed their secondary education and $62.4 \%$ of them were housewives. Also, it was found that $52.6 \%$ of them were belonged to moderate social class.

Table (2): reveals distribution of the studied students according to their current health complains related to symptoms of RTI. As shown in the table, it was noticed that $65.4 \%$ of the studied students in the pre test reported having symptoms of RTI. All students experiencing these complains $(100 \%)$ had abnormal excessive vaginal discharge and itching, while $50.6 \%$ of them had burning sensation with urination . In the post test, these complains slightly decreased but the difference observed wasn't statistically significant, where $(\mathrm{P}$-value $<0.05)$.

Table(3): shows the effect of menstrual education program on students' genital care practices. There were highly statistical significant differences in all practices related to genital care in the post test compared to their practices in the pre test, where (P-value $=0.001)$.

Table(4): shows the effect of menstrual education program on students' choice and care of underwear. As shown in the table, there were highly statistical significant differences in all practices related to choice and care of underwear in the post test compared to the pre test, where $(\mathrm{P}$-value $=0.001)$.

Figure(1): summarizes the total score of the studied students' practices regarding menstrual hygiene. The majority of the students had healthy practice score level regarding menstrual hygiene at the post-test compared to the pre-test. The difference observed was highly statistical significant, where $(\mathrm{P}$-value $=0.001)$.

Table( 5): shows various relieving measures used by the students for relieving their menstrual pain. Data of the pre test elaborates that $58.6 \%$ of the studied students weren't taking any herbal drinks for relieving their pain. Meanwhile, the majority of 
students(87.2\%) reported taking herbal drinks as fenugreek, peppermint, anise cinnamon and ginger in the post test after program implementation. Differences observed were highly statistical significant, where $(\mathrm{P}-$ value $=0.001)$.

Table (6): shows the effect of menstruation on daily activities of the studied students. In the pre test, the majorities of them( $82.7 \%, 74.4 \%, 61.7 \%$ and 54.9\%) abstained from performing normal activities(house hold activities, going to school, performing physical activity and visiting holy places. Meanwhile, In the post test, highly statistical significant differences were seen with regard to the previous items, where $(\mathrm{P}$-value $=0.001)$.

Table (7): shows inadequate provision of health protective measures and basic hygiene supplies in each of the four schools before implementation of the program. None of the four schools provided toilets with soap or toilet paper. $75.0 \%$ of the schools had inadequate water closets/students number and the existing water closets were unclean. After implementation of the program, slight improvement was seen with regard to the previous items, but the differences observed weren't statistically significant, where (P-value $>0.05)$.

Figure(2): shows sources of information about menstruation among the studied students. As shown in the figure, $39.1 \%$ of the students reported that their friends were the main source of information about menstruation followed by their mothers $22.6 \%$, internet $19.6 \%$, grandmother $12.4 \%$, and finally school teachers $6.3 \%$.

Table (8): shows statistical relationship between students' total practice score levels and their social class. As shown in the table, there was a highly statistical significant difference between studied students' social class and their total practice score levels in the post test ,where $\mathrm{P}=0.005$. 
Table (1): Socio-demographic Characteristics of the Studied Students.

\begin{tabular}{|c|c|c|}
\hline $\begin{array}{l}\text { Items } \\
\end{array}$ & No(133) & 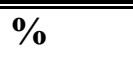 \\
\hline $\begin{array}{l}\text { 1. Age( in years) } \\
15 \\
16 \\
17\end{array}$ & $\begin{array}{l}97 \\
35 \\
1\end{array}$ & $\begin{array}{l}72.9 \\
26.3 \\
0.8\end{array}$ \\
\hline $\begin{array}{l}\text { Mean } \pm \text { SD } \\
\text { Range }\end{array}$ & $\begin{array}{r}15.28= \\
15-17\end{array}$ & \\
\hline $\begin{array}{l}\text { 2. Residence } \\
\text { Urban } \\
\text { Rural }\end{array}$ & $\begin{array}{l}107 \\
26\end{array}$ & $\begin{array}{l}80.5 \\
19.5\end{array}$ \\
\hline $\begin{array}{l}\text { 3. Birth Order } \\
1^{\text {st }} \\
2^{\text {nd }} \\
3-5\end{array}$ & $\begin{array}{l}66 \\
46 \\
21\end{array}$ & $\begin{array}{l}49.6 \\
34.6 \\
15.8\end{array}$ \\
\hline $\begin{array}{l}\text { 4. Mother's educational level } \\
\text { Can't read and write } \\
\text { Read and write } \\
\text { Primary } \\
\text { Secondary } \\
\text { University }\end{array}$ & $\begin{array}{l}3 \\
4 \\
12 \\
71 \\
43\end{array}$ & $\begin{array}{l}2.3 \\
3.0 \\
9.0 \\
53.4 \\
32.3\end{array}$ \\
\hline $\begin{array}{l}\text { 5. Mother's occupation } \\
\text { Housewife } \\
\text { Employee }\end{array}$ & $\begin{array}{l}83 \\
50\end{array}$ & $\begin{array}{l}62.4 \\
37.6\end{array}$ \\
\hline $\begin{array}{l}\text { 6. Father's educational level } \\
\text { Read and write } \\
\text { Primary } \\
\text { Secondary } \\
\text { University } \\
\text { Intermediate institute }\end{array}$ & $\begin{array}{l}11 \\
28 \\
32 \\
46 \\
16\end{array}$ & $\begin{array}{l}8.3 \\
21.0 \\
24.1 \\
34.6 \\
12.0\end{array}$ \\
\hline $\begin{array}{l}\text { 7. Father's occupation } \\
\text { Worker/Farmer } \\
\text { professional } \\
\text { Semi profession/clerk } \\
\text { Trades/business }\end{array}$ & $\begin{array}{l}8 \\
38 \\
54 \\
33\end{array}$ & $\begin{array}{l}6.0 \\
28.6 \\
40.6 \\
24.8\end{array}$ \\
\hline $\begin{array}{l}\text { 8. Family monthly income } \\
\text { Sufficient and save } \\
\text { Just enough } \\
\text { Insufficient }\end{array}$ & $\begin{array}{l}87 \\
37 \\
9 \\
\end{array}$ & $\begin{array}{l}65.4 \\
27.8 \\
6.8 \\
\end{array}$ \\
\hline $\begin{array}{l}\text { 9. Social Class } \\
\text { Low } \\
\text { Moderate } \\
\text { High }\end{array}$ & $\begin{array}{l}10 \\
70 \\
53\end{array}$ & $\begin{array}{l}7.5 \\
52.6 \\
39.8\end{array}$ \\
\hline
\end{tabular}


Table (2): Distribution of the Studied Students According to Their Current Health

Complains Related to Reported Symptoms of RTI.

\begin{tabular}{|l||l||l||l||l||l||l||}
\hline \multirow{2}{*}{ Complains Phases } & \multicolumn{2}{|l||}{ Pre-test } & \multicolumn{2}{l||}{ Post- test } & $\begin{array}{l}\text { Test of } \\
\text { significan } \\
\text { ce } \\
X^{2}\end{array}$ & $\begin{array}{l}\text { P- } \\
\text { value }\end{array}$ \\
\cline { 2 - 7 } & No & $\%$ & No & \% & \\
\hline \hline 1. Current complains & & & & & & \\
Yes & 87 & 65.4 & 81 & 60.9 & 0.582 & 0.45 \\
No & 46 & 34.6 & 52 & 39.1 & & \\
\hline *Type of Complain & & & & & & \\
Excessive Abnormal vaginal discharge & 87 & 100 & 79 & 34.7 & 0.622 & 0.27 \\
Itching & & & & & & \\
Burning sensation with urination & 87 & 100 & 78 & 34.2 & 0.702 & 0.24 \\
Redness in vulva & 44 & 50.6 & 39 & 17.1 & 0.55 & 0.29 \\
Chronic lower abdominal pain & 28 & 32.2 & 42 & 10.5 & 0.556 & 0.29 \\
& 11 & 12.6 & 8 & 3.5 & 0.697 & 0.24 \\
\hline
\end{tabular}

N.B: * "Answers were not mutually exclusive". 
Table (3): Distribution of the Studied Students According to Their Genital Care Practices.

\begin{tabular}{|c|c|c|c|c|c|c|}
\hline \multirow{2}{*}{$\begin{array}{ll}\text { Practice Items } & \text { Phases } \\
\end{array}$} & \multicolumn{2}{|c|}{ Pre-Test } & \multicolumn{2}{|c|}{ Post-Test } & \multirow[t]{2}{*}{ Test } & \multirow[t]{2}{*}{ P value } \\
\hline & No & $\%$ & No. & $\%$ & & \\
\hline $\begin{array}{l}\text { 1. Cleaning genital area whenever } \\
\text { enter toilet or changing pad } \\
\text { Yes } \\
\text { No }\end{array}$ & $\begin{array}{l}75 \\
58 \\
\end{array}$ & $\begin{array}{l}56.4 \\
43.6 \\
\end{array}$ & $\begin{array}{l}125 \\
8 \\
\end{array}$ & $\begin{array}{l}94.0 \\
6.0 \\
\end{array}$ & $\mathbf{X}^{2}=50.4$ & $0.001 * *$ \\
\hline $\begin{array}{l}\text { 2. Method of Cleaning genital area } \\
\text { Only water } \\
\text { Warm water \&soap } \\
\text { Warm water \&antiseptic }\end{array}$ & $\begin{array}{l}110 \\
19 \\
4\end{array}$ & $\begin{array}{l}82.7 \\
14.3 \\
3.0\end{array}$ & $\begin{array}{l}9 \\
107 \\
17\end{array}$ & $\begin{array}{l}6.8 \\
80.5 \\
12.8\end{array}$ & $\mathbf{F E}=217.6$ & $0.001 * *$ \\
\hline $\begin{array}{l}\text { 3. Direction of cleaning genitalia: } \\
\text { Vagino- anal } \\
\text { Ano-vaginal } \\
\text { Any direction } \\
\end{array}$ & $\begin{array}{l}31 \\
62 \\
40 \\
\end{array}$ & $\begin{array}{l}23.3 \\
46.6 \\
30.1 \\
\end{array}$ & $\begin{array}{l}122 \\
4 \\
7 \\
\end{array}$ & $\begin{array}{l}91.7 \\
3.0 \\
5.3 \\
\end{array}$ & $\mathbf{F E}=142.3$ & $0.001 * *$ \\
\hline $\begin{array}{l}\text { 4.Type of pad used: } \\
\text { Piece of clothe } \\
\text { Piece of cotton } \\
\text { Sanitary pad }\end{array}$ & $\begin{array}{l}14 \\
4 \\
115 \\
\end{array}$ & $\begin{array}{l}10.5 \\
3.0 \\
86.5 \\
\end{array}$ & $\begin{array}{l}0 \\
0 \\
133 \\
\end{array}$ & $\begin{array}{l}0.0 \\
0.0 \\
100 \\
\end{array}$ & $\mathbf{F E}=21.33$ & $0.001 * *$ \\
\hline $\begin{array}{l}\text { 5.Frequency of changing pad/day: } \\
\text { Twice daily } \\
3 \text { times/day } \\
4-5 \text { times/day } \\
\text { When pad full } \\
\end{array}$ & $\begin{array}{l}80 \\
14 \\
19 \\
20 \\
\end{array}$ & $\begin{array}{l}60.2 \\
10.5 \\
14.3 \\
15.0 \\
\end{array}$ & $\begin{array}{l}5 \\
8 \\
120 \\
0 \\
\end{array}$ & $\begin{array}{l}3.8 \\
6.0 \\
90.2 \\
0.0 \\
\end{array}$ & $\mathbf{F E}=185.3$ & $0.001 * *$ \\
\hline $\begin{array}{l}\text { 6. Bathing during menses } \\
\text { Once during menstrual period } \\
\text { Daily } \\
\text { Never take bath }\end{array}$ & $\begin{array}{l}24 \\
35 \\
74\end{array}$ & $\begin{array}{l}18.0 \\
26.3 \\
55.6\end{array}$ & $\begin{array}{l}28 \\
88 \\
17\end{array}$ & $\begin{array}{l}21.1 \\
66.2 \\
12.8\end{array}$ & $X^{2}=58.8$ & $0.001 * *$ \\
\hline $\begin{array}{l}\text { 7. Regular removal of pubic hair } \\
\text { Yes } \\
\text { No } \\
\text { Causes of non removal } \\
\text { Mother refuse } \\
\text { Fear of pain } \\
\text { Habit } \\
\end{array}$ & $\begin{array}{l}54 \\
79 \\
\\
64 \\
10 \\
5\end{array}$ & $\begin{array}{l}40.6 \\
59.4 \\
81 \\
12.7 \\
6.3 \\
\end{array}$ & $\begin{array}{l}91 \\
42 \\
42 \\
0 \\
0 \\
\end{array}$ & $\begin{array}{l}68.4 \\
31.6 \\
\\
100 \\
0.0 \\
0.0 \\
\end{array}$ & $\begin{array}{l}X^{2}=20.8 \\
F E=9.1\end{array}$ & $\begin{array}{l}0.001 * * \\
0.008^{* *}\end{array}$ \\
\hline $\begin{array}{l}\text { 8. Applying perfumed materials on } \\
\text { genital area } \\
\text { Yes } \\
\text { No } \\
\end{array}$ & $\begin{array}{l}44 \\
89 \\
\end{array}$ & $\begin{array}{l}33.1 \\
66.9 \\
\end{array}$ & $\begin{array}{l}11 \\
122 \\
\end{array}$ & $\begin{array}{l}8.3 \\
91.7 \\
\end{array}$ & $X^{2}=24.96$ & $0.001 * *$ \\
\hline $\begin{array}{l}\text { 9. Applying Talcum powder on genital } \\
\text { area } \\
\text { Yes } \\
\text { No }\end{array}$ & $\begin{array}{l}49 \\
84 \\
\end{array}$ & $\begin{array}{r}36.8 \\
63.2 \\
\end{array}$ & $\begin{array}{l}14 \\
119 \\
\end{array}$ & $\begin{array}{l}10.5 \\
89.5 \\
\end{array}$ & $\mathbf{X}^{2}=25.5$ & $0.001 * *$ \\
\hline $\begin{array}{l}\text { 10. Washing hands } \\
\text { Only before changing pad } \\
\text { Before \&after changing pad }\end{array}$ & $\begin{array}{l}44 \\
89 \\
\end{array}$ & $\begin{array}{l}33.1 \\
66.9 \\
\end{array}$ & $\begin{array}{l}22 \\
111 \\
\end{array}$ & $\begin{array}{l}16.5 \\
83.5 \\
\end{array}$ & $\mathbf{X}^{2}=9.75$ & $0.002 * *$ \\
\hline
\end{tabular}


Table (4): Distribution of the Studied Students According to Their Choice and Care of underwear.

\begin{tabular}{|c|c|c|c|c|c|c|}
\hline \multirow{2}{*}{\begin{tabular}{|l|} 
\\
Practice Items
\end{tabular}} & \multicolumn{2}{|c|}{ Pre-Test } & \multicolumn{2}{|c|}{ Post-Test } & \multirow[t]{2}{*}{ Test } & \multirow[t]{2}{*}{$P$ value } \\
\hline & No & $\%$ & No & $\%$ & & \\
\hline \multicolumn{7}{|l|}{ 1. Type of underwear } \\
\hline Nylon & 17 & 12.8 & 8 & 6.0 & & \\
\hline Cotton & 70 & 52.6 & 115 & 86.5 & $\mathbf{X}^{2}=37.3$ & $0.001 * *$ \\
\hline Polyester & 46 & 34.6 & 10 & 7.5 & & \\
\hline \multicolumn{7}{|l|}{ 2. Frequency of changing underwear } \\
\hline Twice/ day & 48 & 36.1 & 109 & 82.0 & & \\
\hline Once/day & 35 & 26.3 & 20 & 15.0 & $\mathbf{F E}=73.34$ & $0.001 * *$ \\
\hline Day after day & 50 & 37.6 & 4 & 3.0 & & \\
\hline \multicolumn{7}{|l|}{ 3. Methods of Cleaning underwear } \\
\hline Water \&soap in the washing machine & 62 & 46.6 & 18 & 13.5 & & \\
\hline Boiled water \& soap separate from other & 71 & 53.4 & 115 & 86.5 & $\mathbf{X}^{2}=34.6$ & $0.001 * *$ \\
\hline clothes & & & & & & \\
\hline \multicolumn{7}{|l|}{ 4. Methods of drying underwear } \\
\hline Away from sunrays & 61 & 45.9 & 27 & 20.3 & & \\
\hline Under direct sunrays & 72 & 54.1 & 106 & 79.7 & $\mathbf{X}^{2}=19.6$ & $0.001 * *$ \\
\hline \multicolumn{7}{|l|}{ 5. Methods of pad disposal } \\
\hline Throwed covered in recycle bin & 94 & 70.7 & 129 & 97.0 & & \\
\hline Throwed on road side & 1 & 0.8 & 0 & 0.0 & $\mathbf{F E}=37.2$ & $0.001 * *$ \\
\hline Throwed in toilet & 38 & 28.5 & 4 & 3.0 & & \\
\hline
\end{tabular}




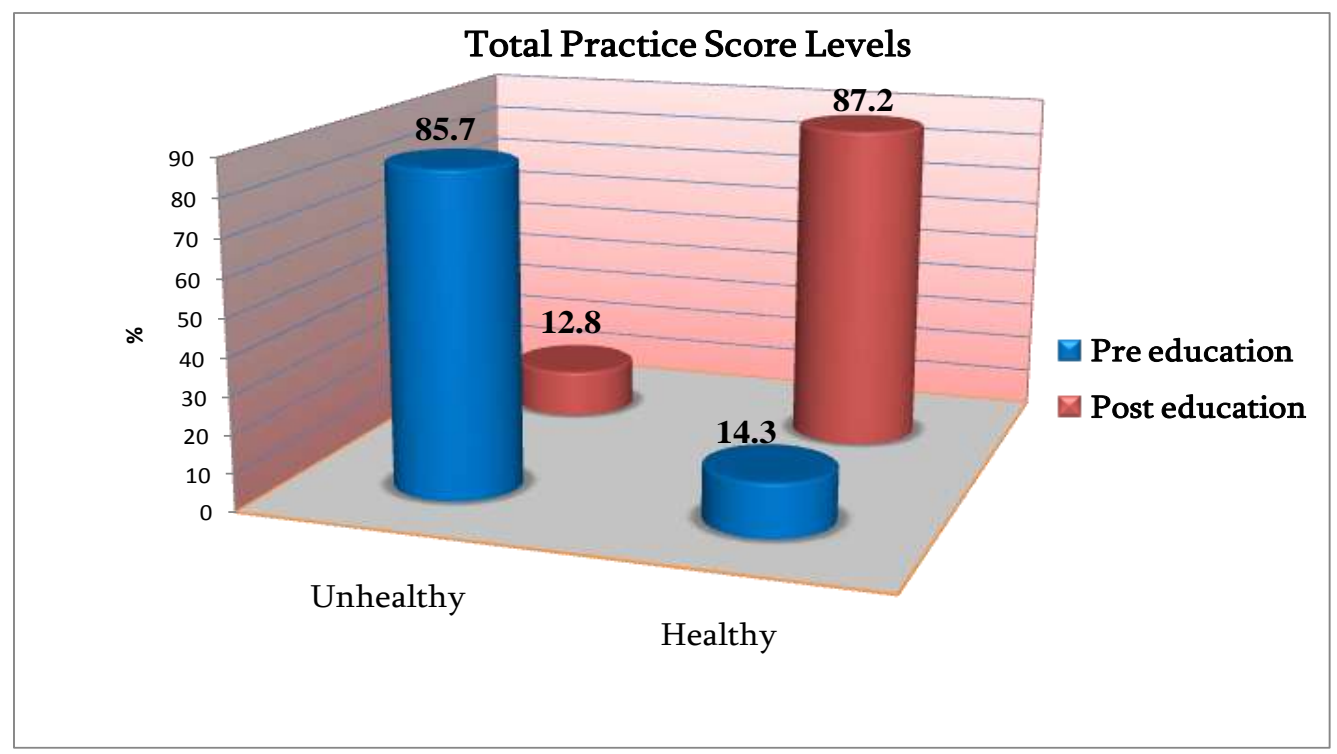

Figure (1): Distribution of the Studied Students according to their Total Practice Score Levels. 
Table (5): Distribution of the Studied Students According to Their Pain Relief Behaviors.

\begin{tabular}{|c|c|c|c|c|c|c|}
\hline \multirow{2}{*}{\begin{tabular}{|lr} 
Behaviors & Phases \\
\end{tabular}} & \multicolumn{2}{|c|}{ Pre-test } & \multicolumn{2}{|c|}{ Post-test } & \multirow[t]{2}{*}{ Test } & \multirow[t]{2}{*}{ P-value } \\
\hline & No & $\%$ & $\overline{\text { No }}$ & $\%$ & & \\
\hline \multicolumn{7}{|l|}{ 1. Taking herbal drinks } \\
\hline Yes & 55 & 41.4 & 116 & 87.2 & $X^{2}=60.9$ & $0.001 * *$ \\
\hline No & 78 & 58.6 & 17 & 12.8 & & \\
\hline \multicolumn{7}{|l|}{ *Type of herbs } \\
\hline Fenugreek & 34 & 61.8 & 98 & 84.5 & Z6.37 & $0.001 * *$ \\
\hline Peppermint & 8 & 15.5 & 78 & 67.2 & Z 12.99 & $0.001 * *$ \\
\hline Anise & 10 & 18.2 & 64 & 55.2 & Z 8.65 & $0.001 * *$ \\
\hline Cinnamon & 3 & 5.5 & 47 & 40.5 & Z 13.1 & $0.001 * *$ \\
\hline Ginger & 0 & 0.0 & 33 & 28.4 & - & - \\
\hline \multicolumn{7}{|l|}{ 2. Avoiding certain foods } \\
\hline Yes & 21 & 15.8 & 108 & 81.2 & $X^{2}=113.9$ & $0.001 * *$ \\
\hline No & 112 & 84.2 & 25 & 18.8 & & \\
\hline \multicolumn{7}{|l|}{ *Type of foods } \\
\hline Fast foods & 6 & 28.6 & 59 & 54.6 & $Z=11.36$ & $0.001 * *$ \\
\hline High sugar diet & 4 & 19.0 & 43 & 39.8 & $Z=10.2$ & $0.001 * *$ \\
\hline Caffeinated foods & 3 & 14.3 & 44 & 40.7 & $Z=12.23$ & $0.001 * *$ \\
\hline Cold drinks & 5 & 23.8 & 44 & 40.7 & $Z=9.2$ & $0.001 * *$ \\
\hline High salt diet & 3 & 14.3 & 35 & 32.4 & $Z=9.6$ & $0.001 * *$ \\
\hline \multicolumn{7}{|c|}{$\begin{array}{l}\text { 3. Applying heating bag for } \\
\text { pain relief }\end{array}$} \\
\hline Yes & 26 & 19.5 & 101 & 75.9 & $\mathrm{FE}=84.8$ & $0.001 * *$ \\
\hline No & 107 & 80.5 & 32 & 24.1 & & \\
\hline \multicolumn{7}{|l|}{ 4. Taking medications } \\
\hline Yes & 79 & 59.4 & 23 & 17.3 & $X^{2}=49.9$ & $0.001 * *$ \\
\hline No & 54 & 40.6 & 110 & 82.7 & & \\
\hline \multicolumn{7}{|l|}{ Type of medication } \\
\hline Analgesics & 70 & 88.6 & 23 & 100.0 & $\mathrm{FE}=1.53$ & 0.217 \\
\hline Antispasmodics & 9 & 11.4 & 0 & 0.0 & & \\
\hline
\end{tabular}

N.B: * "Answers were not mutually exclusive". 
Table (6): Distribution of the Studied Students According to Their Restrictions during

Menstruation.

\begin{tabular}{|c|c|c|c|c|c|c|}
\hline Phases & Pre- & & Post- & & 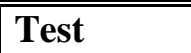 & P-value \\
\hline Behavior & No & $\%$ & $\overline{\text { No }}$ & $\%$ & & \\
\hline $\begin{array}{l}\text { 1. Going to school in the first } \\
\text { menstrual day } \\
\text { Yes } \\
\text { No }\end{array}$ & $\begin{array}{l}51 \\
82\end{array}$ & $\begin{array}{l}38.3 \\
61.7\end{array}$ & $\begin{array}{l}114 \\
19\end{array}$ & $\begin{array}{l}85.7 \\
14.3\end{array}$ & $\mathbf{X}^{2}=63.4$ & $0.001 * *$ \\
\hline $\begin{array}{l}\text { 2. Performing household activities } \\
\text { Yes } \\
\text { No }\end{array}$ & $\begin{array}{l}60 \\
73\end{array}$ & $\begin{array}{l}45.1 \\
54.9\end{array}$ & $\begin{array}{l}114 \\
19\end{array}$ & $\begin{array}{l}85.7 \\
14.3\end{array}$ & $\mathbf{X}^{2}=48.5$ & $0.001 * *$ \\
\hline $\begin{array}{l}\text { 3. Physical activity during menses } \\
\text { Yes } \\
\text { No }\end{array}$ & $\begin{array}{l}34 \\
99\end{array}$ & $\begin{array}{l}25.6 \\
74.4\end{array}$ & $\begin{array}{l}107 \\
26\end{array}$ & $\begin{array}{l}80.5 \\
19.5\end{array}$ & $\mathbf{F E}=80.4$ & $0.001 * *$ \\
\hline $\begin{array}{l}\text { 4. Visiting friends and relatives } \\
\text { during menstrual days } \\
\text { Yes } \\
\text { No }\end{array}$ & $\begin{array}{l}110 \\
23\end{array}$ & $\begin{array}{l}82.7 \\
17.3\end{array}$ & $\begin{array}{l}123 \\
10\end{array}$ & $\begin{array}{l}92.5 \\
7.5\end{array}$ & $\mathbf{X}^{2}=5.8$ & $0.016 *$ \\
\hline $\begin{array}{llll}\text { 5. Visiting holy places during } \\
\text { menstruation } & & \\
\text { Yes } & & & \\
\text { No } & & & \\
& & & \\
& & & \\
& & & \\
& & & \\
& & & \\
\end{array}$ & $\begin{array}{l}23 \\
110\end{array}$ & $\begin{array}{l}17.3 \\
82.7\end{array}$ & $\begin{array}{l}115 \\
18\end{array}$ & $\begin{array}{l}86.5 \\
13.5\end{array}$ & $\mathbf{X}^{2}=127.46$ & $0.001 * *$ \\
\hline
\end{tabular}




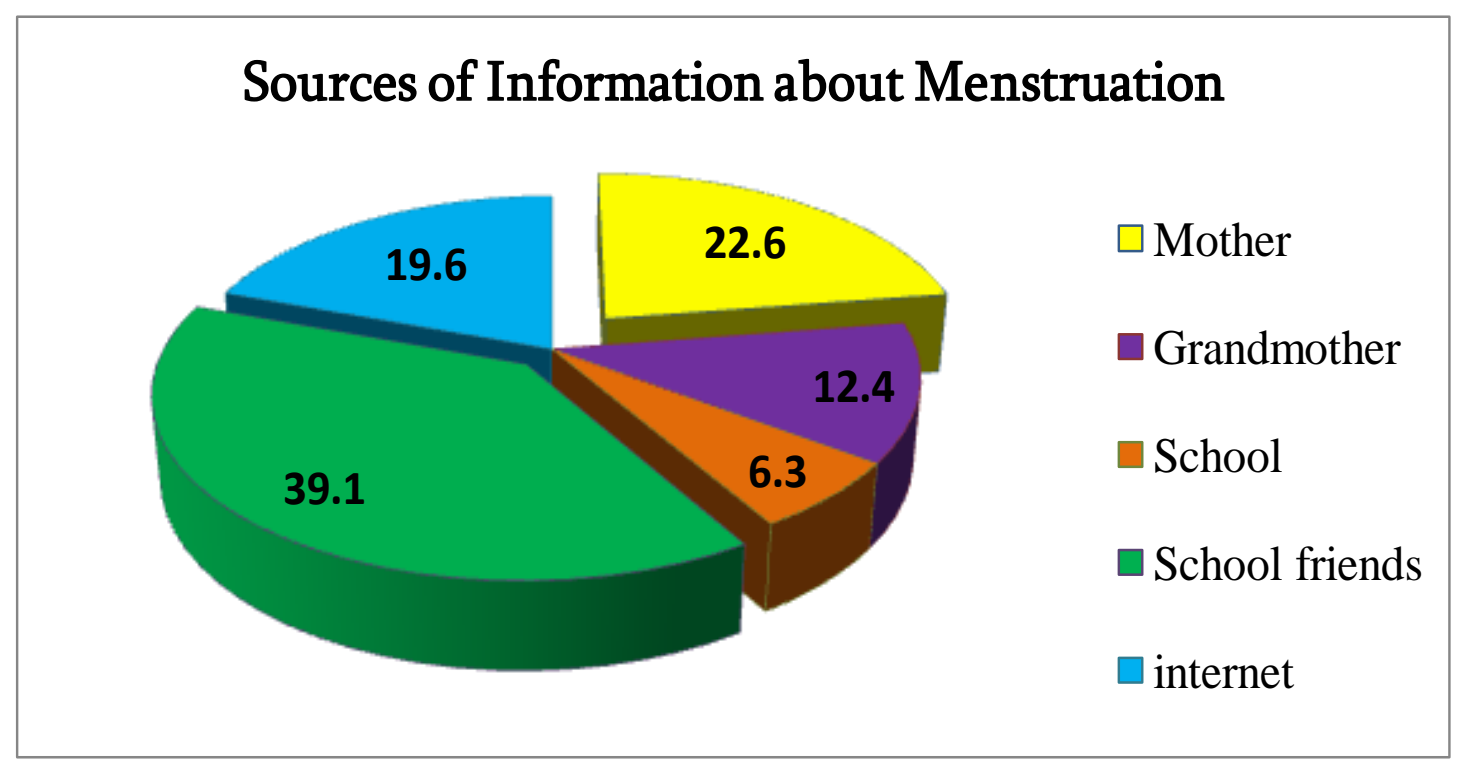

Figure(2):Distribution of the Studied Students According to Sources of Information About Menstruation. 
Table (7):Distribution of the Secondary Schools For girls in the City of Damietta According to the Availability of Health Protective Measures in Each School (N=4).

\begin{tabular}{|c|c|c|c|c|c|c|}
\hline \multirow{2}{*}{\begin{tabular}{|ll} 
Measures & Phases \\
\end{tabular}} & \multicolumn{2}{|c|}{ Pre-test } & \multicolumn{2}{|c|}{ Post- test } & \multirow{2}{*}{$\begin{array}{l}\text { FE } \\
\text { Test }\end{array}$} & \multirow[t]{2}{*}{ P-value } \\
\hline & No & $\%$ & No & $\%$ & & \\
\hline \multicolumn{7}{|l|}{ Water Closets/students number } \\
\hline Adequate & 1 & 25.0 & 1 & 25.0 & 0.667 & 0.414 \\
\hline Inadequate & 3 & 75.0 & 3 & 75.0 & & \\
\hline Cleanliness of Water Closets' floors & & & & & & 0.414 \\
\hline Clean & 0 & 0.0 & 2 & 50.0 & 0.667 & \\
\hline Not clean & 4 & 100.0 & 2 & 50.0 & & \\
\hline Toilet Seats & 1 & & & & 0.50 & 0.48 \\
\hline Clean & 3 & 25.0 & 3 & 75.0 & & \\
\hline Not clean & & 75.0 & 1 & 25.0 & - & \\
\hline Water Supply & 4 & & & & & - \\
\hline Available & 0 & 100.0 & 4 & 100.0 & 1.2 & \\
\hline Not available & & 0.0 & 0 & 0.0 & & 0.55 \\
\hline Basins for hand washing & 2 & & & & 0.50 & 0.48 \\
\hline Available & 1 & 50.0 & 3 & 75.0 & & \\
\hline Available but broken & 1 & 25.0 & 0 & 0.0 & & \\
\hline Not available & & 25.0 & 1 & 25.0 & 2.13 & \\
\hline Location of the Basins & 2 & & & & & 0.144 \\
\hline Inside water closets & 2 & 50.0 & 2 & 50.0 & & \\
\hline Outside water closets & & 50.0 & 2 & 50.0 & & \\
\hline Soap or disinfectant solution for hand & 0 & & & & & \\
\hline washing & 4 & 0.0 & 3 & 75.0 & 2.13 & 0.144 \\
\hline Available & & 100.0 & 1 & 25.0 & & \\
\hline Not available & 0 & & & & & \\
\hline Toilet paper & 4 & 0.0 & 1 & 25.0 & 2.33 & \\
\hline Available & & 100.0 & 3 & 75.0 & & 0.311 \\
\hline Not available & 1 & & & & & \\
\hline Number of baskets as waste disposal & 2 & 25.0 & 3 & 75.0 & 0.0 & \\
\hline Adequate & 1 & 50.0 & 1 & 25.0 & & 1.0 \\
\hline Inadequate & & 25.0 & 0 & 0.0 & & \\
\hline Absent & & & & & & \\
\hline Doors and windows of water closets & 2 & 50.0 & 3 & & & \\
\hline have bolts & 2 & 50.0 & 1 & 75.0 & & \\
\hline Yes & & & & 25.0 & & \\
\hline No & & & & & & \\
\hline
\end{tabular}


Table (8): Statistical Relationship Between Students' Total Practice Score Levels and Their Social Class.

\begin{tabular}{|c|c|c|c|c|c|c|}
\hline \multirow[b]{3}{*}{ Social Class } & \multicolumn{4}{|c|}{ Post-test } & \multirow[t]{3}{*}{ Test } & \multirow{3}{*}{$\begin{array}{l}\text { P- } \\
\text { Value }\end{array}$} \\
\hline & \multicolumn{2}{|c|}{ Unhealthy } & \multicolumn{2}{|c|}{$\overline{\text { Healthy }}$} & & \\
\hline & No & \%\% & "No & $\overline{\%}$ & & \\
\hline $\begin{array}{l}\text { Social class } \\
\text { Low }\end{array}$ & & & & & & \\
\hline Moderate & 5 & 29.4 & 5 & 4.3 & 10.04 & 0.005 \\
\hline High & $\begin{array}{l}8 \\
4\end{array}$ & $\begin{array}{l}47.1 \\
23.5\end{array}$ & $\begin{array}{l}62 \\
49\end{array}$ & $\begin{array}{l}53.4 \\
42.2\end{array}$ & & ** \\
\hline
\end{tabular}

Not significant P>0.05 *Significant $P<0.05 \quad * *$ Highly significant $P \leq 0.00$

\section{DISCUSSION:}

The aim of the present study was to evaluate the effect of health education program on menstrual practices among secondary school girls. Regarding socio-demographic characteristics of the studied students, the results showed that, the mean age of students was 15.28 \pm 0.47 years. This result is in line with Marzouk et al.,(2013), who mentioned that the mean age of students was 16.1 years.

Concerning the reported symptoms of (RTI) among students, findings showed that more than two thirds of the studied students had symptoms of RTI. This study illustrated that all students experiencing RTI symptoms, had vaginal itching and abnormal vaginal discharge. This finding is in the same line with Mohamed (2013) who mentioned nearly the same percentage. The high prevalence of RTI symptoms in this study is probably due to poor hygienic practices among students which aggravated by unhygienic conditions at school.

After implementation of the educational program, the percentage of students having symptoms of RTI decreased but it didn't show any significance between pre and posttest. This could be attributed to that students can adopt healthy practices and change their unhealthy behaviors in a short period, but the disappearance of these symptoms needs more time in order to disappear, especially as those problems may be chronic symptoms. 
Hygiene related practices of women during menstruation are of considerable importance as it affects health by increasing vulnerability to infection especially RTIs. Good hygiene, such as use of sanitary pads, is essential during menstruation. Findings revealed that the majority of the studied students used sanitary pads in the pre-test period which increased in the post- test to includes all students. This finding is supported by El-Lassy and Madian (2013) who found that the majority of girls used sanitary pads during menses in the pre-test which increased at the post- test.

Changing and care of underwear are also important components of feminine hygiene. It is astonishing to see that, more than one- third of the students changed their underwear day after day. This might be attributed to lack of awareness about this hygienic practice and they weren't aware of the seriousness of this and its role in the incidence of many genital diseases. This result declined in the post- test, where the majorities of students reported changing their underwear twice daily. This finding is in line with Nemade et al (2009) who found that there was significant improvement in the practice related to changing underwear among the study sample.

Regarding students' total practice score levels, the results showed that the majority of students had unhealthy practice score level regarding all aspects related to menstrual hygiene in the pre -test. This was expected which could be mainly due to some cultural restrictions preventing the flow of correct and sufficient information given to youngsters. After implementation of the study program, there was a highly statistical significant difference in the students' total practice score levels between pre and posttest. This finding is in accordance with Gafer,(2013) who found highly statistical significant difference in students' total practice score level between pre and post- test. In addition, Premila et al.,(2015) who revealed that there was a significant difference between the pre and post- test level of practice regarding menstrual hygiene.

Considering the effect of menstruations on daily activities of the students, more than half of the studied students abstained from performing house hold activities and the majority of them restricted physical activities(exercise) during menstruation in the pre- test. This result agreed with Marzouk et al.,(2013) who revealed that more than half of the study sample abstained from performing normal activities. After implementation of the educational program the majority of students mentioned that 
they begin to perform household and physical activities during their menstrual cycle. This result is in line with El-Lassy and Madian (2013) who revealed that there was a significant improvement regarding students' performance of household activities during menstruation in the post- test

Regarding the source of information about menstruation, findings revealed that more than one third of the studied students reported their friends as the main source of information about menstruation and only more than one fifth of them preferred to consult their mothers. This could be attributed to that many young girls identified their peers as the best source for sharing, and talking about their problems. This is supported by Rajni et al,(2009), who found that friends were the most important source of information among girls.

Concerning statistical relationship between students' total practice score levels and their social class, finding showed that there was a highly statistical significant relation between students' total practice score level and their social class in the posttest. This finding could be attributed to good literacy and socio-economic status of students belonged to moderate and high social class, where students have access to basic facilities such as water, clean bathrooms, privacy, and are able to buy sanitary pads and other feminine hygiene products that enable them to maintain good hygienic practices. This finding is in line with Gafer, (2013) who mentioned that students social class showed significant influence on girls' practice score .

\section{CONCLUSION:}

\section{Based on the present study findings, it can be concluded that:}

The majority of the studied students had unhealthy menstrual practices and abstained from performing normal activities(house hold and physical activities, school attendance, and visiting holy places) during their menstrual cycle in the pre-test. After implementation of the educational program significant improvement with highly statistical significant differences were noticed in students' practices and behaviors during menstruation. Therefore, the educational program was successful in attaining its aim of positively changing practices and behaviors of the studied students regarding menstruation. 


\section{RECOMMENDATIONS:}

1. School health nurse should provide loud and clear messages on menstrual hygiene for adolescent girls and their mothers which can be achieved through parent meetings and group discussion based on scientific facts, considering physical, social and mental changes of adolescent girls.

2. Secondary school students need to be supported with clean school environment supplied with clean bathrooms in addition to other basic hygienic products to help them manage their hygiene.

3. Further additional studies may be needed using a wider geographic scope and a larger sample size that should include young girls and their mothers emphasizing cultural variations in order to provide sufficient and comprehensive information in all Egyptian governorates.

\section{REFERENCES:}

Abd El-Hameed, NA., Mohamed, MS., Ahmed, NH., and Ahmed, ER.,( 2011): Assessment of Dysmenorrhea and Menstrual Hygiene Practices among Adolescent Girls in Some Nursing Schools at EL-Minia Governorate, Egypt, Journal of American Science; 7(9) P 217.

Abd-Ella, N., (2010): Premenarcheal Heath Education Needs among Early Adolescent Girls, Doctorate Thesis, Faculty of Nursing, University of Alexandria. P.p 27, 89.

Abd Allah, E.S., and Elsabagh, E.E., (2011):Impact of Health Education Intervention on Knowledge and Practice about Menstruation among Female Secondary School Students in Zagazig City. Journal of American Science; 7(9)P.p737:747.

Adika V., Ayinde M., and Ide J., (2013): Self-care Practices of Menstrual Hygiene among Adolescents School Going Girls in Amassoma Community, Bayelsa State, International Journal of Nursing and Midwifery;5(5):104. 
Aniebue, U., Aniebue, P., and Nwankwo, O., (2009): The Impact of Pre-Menarcheal Training on Menstrual Practices and Hygiene of Nigerian School Girls, Pan African Medical Journal; 2(9).

Dasgupta, A., Sarkar, M., (2008): Menstrual hygiene: How Hygienic is the Adolescent Girl? Indian Journal of Community Medicine; 33 (2)P.p77-80.

Datta, A., Manna, N., Datta, B., Sarkar, J., Baur, B., and Datta, S., (2012): Menstruation and Menstrual Hygiene Among Adolescent Girls of West Bengal, India: A school based comparative study GJMEDPH; 1(5)P.p 50- 57.

Dube S., and Sharma K., (2012): Knowledge, Attitude and Practice Regarding Reproductive Health among Urban and Rural Girls: A Comparative Study, Ethno Med; $6(2): 85$.

El-Gilany, A., El-Wehad, y A., and El-Wasify, M.,(2012):Updating and validation of the socioeconomic status scale for health research in Egypt. East Mediterr Health Journal; 18(9):P.p962:968.

El-Lassy, R.B, and Madian, A.E.,(2013): Impact of Health Education Program on Menstrual Beliefs and Practices of Adolescent Egyptian Girls at Secondary Technical Nursing School. Life Science Journal;10(2) P 341.

Gafer, H.A., (2013): Effect of Guideline Instructions on Preparatory School Girls regarding Menstrual Health Habits in Benha City. Unpublished Doctorate Thesis, Faculty of Nursing, Benha University.

Juyal, R., and Negi , K.,(2012): Practices of Menstrual Hygiene among Adolescent Girls in a District of Uttarakhand. Ind J Comm Health;24(2)P.p124- 8.

Marzouk, S.A., Alam El-dien, H., Thabet, R.A., and El Zaher, AM., (2013): Impact of Educational Program about Menarche on Improving Student's Self- Concept at Assiut Governorate, Life Science Journal;10(1) P860. 
Mohamed, H.A., (2013): Health Practices among Female University Students regarding

Prevention of Reproductive Tract Infections. Master Thesis, Faculty of Nursing, Benha University, P21.

Nemade, D., Anjenaya, S., and Gujar, R., (2009): Impact of Health Education on Knowledge and Practices About Menstruation Among Adolescent School Girls of Kalamboli, Navimumbai. Health and Population: Perspectives and Issues; 32 (4)P.p167,168.

Premila, E., Ganesh, K ., and Chaitanya, L.,(2015): Impact of Planned Health Education Programme on Knowledge and Practices Regarding Menstrual Hygiene Among Adolescent Girls Studying in Selected High School in Puducherry, India. Asia Pacific Journal of Resesrch;1(5).

Rajni, D., Anil, K., and Manpreet, K., (2009): Knowledge and Practices Related to Menstruation among Tribal(Gujjar) Adolescent Girls. Ethno-Med; 3(1): P.p 43-48.

Shah, S.P., Nair, R., Shah, P.P., Modi, D.K., Desai, S.A., and Desai, L.,(2013): Improving Quality of Life with New Menstrual Hygiene Practices among Adolescent Tribal Girls in Rural Gujarat, India. Reproductive Health Matters; 21(41) P 205:213.

Sowmya, H., and Mohan, S., (2012): Knowledge and Practices of Reproductive Health among School Going Rural Adolescent Girls of Sullia Taluk, Elixir Soc. Sci; 50(1). Available online at www.elixirpublishers.com (Elixir International Journal). 


\section{تأثير برنامج التثقيف الصحى على الممارسات المتعلقة بالحيض بين طالبات المرحلة الثانوية}

\section{هبة على حامد 1 ـ أ.د / عفت محمد القرملاوى2 ــ د/ نجلاء إبراهيم غيدة 3 ـ د/ فاطمة الإمام حافظ 4}

1ماجستير تمريض صحة المجتمع - كلية التمريض- جامعة بنها/ 2 أستاذ تمريض صحة المجتمع - كلية

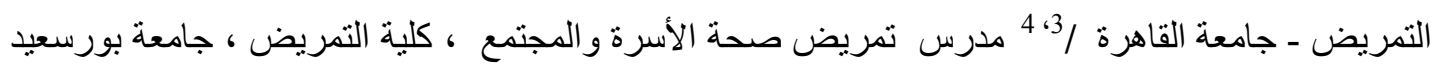

\section{الـخلاصة}

يعتبر الحيض من أهم التغيرات التى تحدث خلال فترة المراهقة وتهدف هذه الدرسة إلى تقييم تأثير برنامج التثقيف الصحى على ممارسات طالبات المرحلة الثانوية تجاه الحيض وقد تم إستخدام تصميم شبه تجريبى خضع لهيع لتقييم قبل وبعد لتنفيذ هذه الدراسة. و أجريت الدراسة فى أربعة ددارس للثانوية العامة للفتيات فى مدينة دمياط، وقد اثتملت عينة الدراسة علي 133 طالبة. تم استخدام استمارة استبيان و إستمارة ملاحظة لتجميع البيانات الخاصة بالدراسة، وقد أسفرت النتائج على أن 65.7\% من الطالبات عانين من أعر اض عدوى الجهاز التناسلى وقد انخفضت تلك الأعر اض تدريجيا بعد نطبيق البرنامج ولكن بدون وجود فروق ذات دلاله إحصائية.

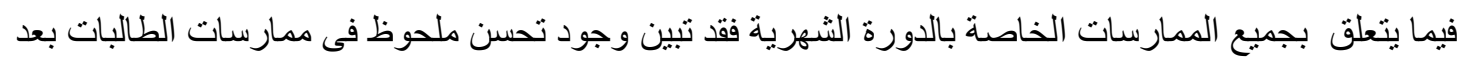
تطبيق البرنامج مع وجود فروق ذات دلالة إحصائية عاليه، وقد تبين أن أغلبية الطالبات يتجنبن ممارسة الأنشطة

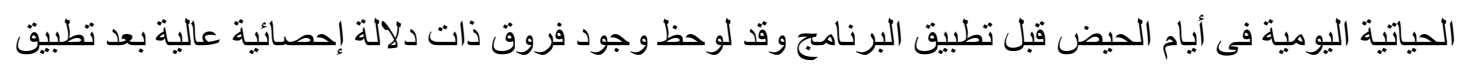
البرنامج. كما ثبت أن هنالك فروق ذات دلالة إحصائية بين ممارسات الطالبات والمستوى الإجتماعى ،وتتلخص لهص

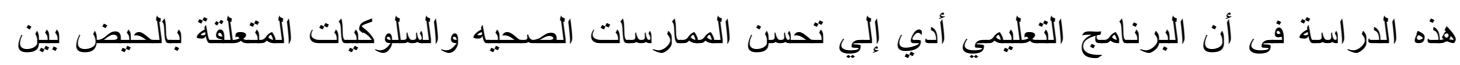

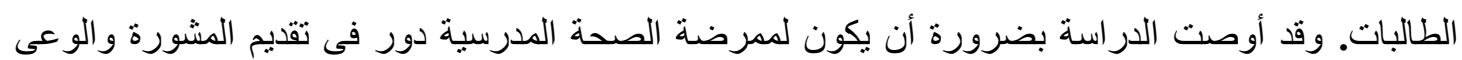
الصحى للطالبات و أمهاتهن وذللك على أساس علمى مع الأخذ فى الاعتبار الاحتباجات الجسمانية والإجتماعية و العقلية للطالبات،كما يجب على إدارة المدرسة أن تدعم بيئة مدرسية صحية للطالبات وذللك من خلال نوفير الطي دور ات مياه نظيفة تحتوى على الادوات الاساسية التى تمكن الطالبات من الحفاظ على نظافتهن. 